\title{
Dual-Band Frequency Absorber Based on Split-Ring Resonators for WiMAX and WLAN Bands
}

\author{
Alparslan Cinar $^{1 *}$, S. Cumhur Basaran ${ }^{2}$ \\ 1* Akdeniz University, Elmali Vocational School, Antalya, Turkey (ORCID: 0000-0002-9113-6549), alparslancinar@ akdeniz.edu.tr \\ 2 Akdeniz University, Faculty of Engineering, Department of Electrical Electronics Engineering, Antalya, Turkey (ORCID: 0000-0001-6432-4512), \\ cbasaran@akdeniz.edu.tr
}

(3rd International Congress on Human-Computer Interaction, Optimization and Robotic Applications June 11-13, 2021)

(DOI: 10.31590/ejosat.946574)

ATIF/REFERENCE: Cinar, A. \& Basaran, S.C. (2021). Dual-Band Frequency Absorber Based on Split-Ring Resonators for WiMAX and WLAN Bands. European Journal of Science and Technology, (26), 151-154.

\begin{abstract}
In this paper, a dual-band compact absorber design based on split-ring resonator for WiMAX and WLAN bands is presented. Top plate of a unit cell in the proposed design is composed of three concentric circular split ring (SR) elements covers an area of $\pi \times 13.42$ $\mathrm{mm}^{2}$ and placed on a FR4 substrate with $1.5 \mathrm{~mm}$ thickness, dielectric constant of 4.3 and loss tangent of 0.025 . Also, six miniature metallic loadings are appropriately inserted between the SR elements. The back side of the substrate is covered full ground plane for shielding transmission from port 1 to port 2. In the design, SR elements are primary resonator of the proposed absorber and provide a dual band of absorption at the respective frequencies. The metallic loadings are used for fine frequency tuning where the absorption peaks occur. Hence, the absorption frequency of the design can be easily tuned by means of sliding the loadings between the rings without changing any design parameters. The proposed compact absorber excited by incident electromagnetic wave provides 0.92 and 0.97 absorption peaks at 3.52 GHz WiMAX and 5.16 GHz WLAN bands, respectively. The design and analysis of the absorber are performed by means of CST Microwave Studio based on frequency domain solver. In this paper, the absorber design with novel configuration is introduced in detail and its corresponding electric field distributions and absorption characteristics at the related bands are presented. Also, the proposed SRR-based absorber design is compared with the previously reported dual or multi bands absorbers in terms of dimensions, resonance frequencies and number of bands.
\end{abstract}

Keywords: Dual Band Absorber, Split Ring Resonator, WiMAX/WLAN Absorber, Small Size.

\section{WiMAX ve WLAN Bantları için Ayrık Halka Rezonatör Tabanlı Çift Bant Frekanslı Soğurucu}

Öz

$\mathrm{Bu}$ çalışmada, WiMAX ve WLAN bantları için ayrık halkalı rezonatör tabanlı bir çift bantlı kompakt soğurucu tasarımı sunulmaktadır. Önerilen tasarımdaki bir birim hücre yapısının üst katmanı, $\pi \times 13.422 \mathrm{~mm}^{2}{ }^{\prime}$ lik bir alanı kaplayan ve $1.5 \mathrm{~mm}$ kalınlığa, 4.3 dielektrik sabiti ve 0.025 kayıp tanjanta sahip bir FR4 taban malzemesi üzerine yerleştirilmiş üç adet eş merkezli dairesel ayrık halka (SR) elemanından oluşur. Ek olarak, SR elemanların arasına altı adet minyatür metalik yükler uygun şekilde yerleştirilmiştir. Giriş kapısı 1'den giriş kapısı 2'ye iletimi engellemek için, taban malzemesinin arka yüzeyi tamamen bakırdan oluşan toprak düzlem ile kaplanmıştır. Tasarımda, SR elemanları önerilen soğurucunun temel rezonatörüdür ve ilgili frekanslarda ikili bir soğurma bandı sağlar. Metalik yükler, soğurma tepe noktalarının meydana geldiği yerlerde ince frekans ayarı yapmak için kullanılır. Böylelikle herhangi bir tasarım parametresi değiştirilmeden yüklerin halkalar arasında kaydırılmasıyla tasarımın soğurma frekansı kolaylıkla

* Corresponding Author: alparslancinar@akdeniz.edu.tr 
ayarlanabilir. Önerilen kompakt soğurucu, gelen elektromanyetik dalgayla uyarılarak sırasıyla 3.52 GHz WiMAX ve 5.16 GHz WLAN bantlarında 0.92 ve 0.97 seviyelere sahip soğurma tepeleri sağlamaktadır. Soğurucu tasarım ve analizleri, CST Microwave Studio (MWS) yazılım programı yardımıyla frequency domain çözümleyicisi kullanılarak gerçekleştirilmiştir. Bu çalışmada, özgün konfigürasyonlu soğurucu tasarımı ayrıntılı bir şekilde tanıtılmış ve ilgili bantlara karşılık gelen elektrik alan dağılımları ve soğurma özellikleri sunulmuştur. Bununla birlikte önerilen SRR tabanlı soğurucu tasarımı, boyutları, rezonans frekansları ve bant sayıları açısından daha önce bildirilen çift veya çok bantlı soğurucularla karşılaştırılmıştır.

Anahtar Kelimeler: Dual Bant Soğurucu, Ayrık Halkalı Rezonatör, WiMAX/WLAN Soğurucu, Küçük Boyut.

\section{Introduction}

Metamaterial electromagnetic wave absorbers have become a popular research topic for more than decades (Landy et al., 2008). The metamaterial-based absorber designed is usually formatted in the style of patch at the top on lossy dielectric layer and the ground at the bottom of lossy dielectric layer. These absorber structures can offer advantages such as flexibility, low profile, easy fabrication and compactness. Because of these features, the absorbers have a wide research area such as emitters (Liu et al., 2011) sensors (Jain et al., 2021), energy harvesting (Bakir et al., 2016), amplitude modulation [5], switching (Ekmekci \& Demir, 2015), EMI/EMC (Mishra et al., 2018; Genikala \& Ghosh, 2020) and WiMAX/WLAN application (Sen et al., 2016; Sen \& Ghosh, 2019). The metametarial structures whose advantages have been described above have the disadvantage of having a narrow absorbent bandwidth. Thus, dual/multi band absorbers have been designed using specially shaped concentric loops in order to defeat this disadvantage (Tak \& Choi, 2016; Wang, 2016). For the same purpose, an absorber design with four different scale flower shaped resonators has been reported to obtain four absorption bands in Reference (Zheng et al., 2013). Additionality, a dual band response has been observed by using a unit cell with four numbers of two scales of Jerusalem resonators in Reference (Zhai et al., 2013). Similarly, a tri-band absorber has been presented by using a unit cell with six numbers of three scales of pentagon resonators in (Guo et al., 2013). In another study, a triband absorber consisting of three concentric rings has been proposed in (Deng et al., 2018). However, the unit cell sizes of the dual/multi-band absorber designs proposed in (Tak \& Choi, 2016; Wang, 2016; Zheng et al., 2013; Zhai et al., 2013; Guo et al., 2013; Deng et al., 2018) are relatively large due to their multiple resonator structures.

In order to overcome the narrow bandwidth limit, a miniaturized dual band absorber is designed in this study. The primary resonator of the absorber consists of two circular concentric SR elements and six miniature metallic loadings placed between the rings. As known, split ring resonators (SRR) are inherently smaller in size than conventional resonator structures, and they exhibit dual band performance with satisfactory radiation characteristics as reported in (Wang, 2016; Basaran \& Erdemli, 2008; Cinar \& Basaran, 2018).

In the proposed design, while SR elements provides dual band absorption, the metallic loadings enable fine frequency tuning of the bands where the absorption peaks occur. The proposed absorber can cover both WiMAX (3.5 GHz) and WLAN $(5.2 \mathrm{GHz})$ bands simultaneously and it has a smaller structure as compared to the absorber designs having dual-band and multiband operation presented in References (Zheng et al., 2013; Zhai et al., 2013; Guo et al., 2013; Deng et al., 2018).
The proposed absorber design can be used in potential applications such as EMI/EMC, wireless communication and WiMAX/WLAN band operations. For example, due to the small size of the SRR, it can be useful in the design of some EMI / EMCs. In addition, it can eliminate the harmful effects on the human body by protecting the electromagnetic wave radiation originating from WiMAX / WLAN.

\section{SRR Based Dual-Band Frequency Absorber Design}

Schematic view of the proposed split ring absorber with design parameters is depicted in Figure 1. Main resonator patch of the absorber in the top plate consists of three concentric circular split ring elements. The outer-most ring with two splits is rather wider than the inner rings with one split each. As seen, six miniature metallic loadings $\left(\mathrm{s}_{1}-\mathrm{s}_{6}\right)$ appropriately located between the rings have a size $1.0 \times 1.2 \mathrm{~mm}^{2}$. A full ground plane is placed in bottom plate to shield transmission from port 1 to port 2. The top resonator plate and ground plane made of copper having a thickness of $0.035 \mathrm{~mm}$ and a conductivity of $5.8 \times 10^{7}$ $\mathrm{S} / \mathrm{m}$. In addition, FR4 with thickness of $1.5 \mathrm{~mm}$, relative permittivity $\varepsilon_{r}$ of 4.3 and loss tangent $(\delta)$ of 0.025 is used for dielectric substrate layers of the absorber. The design and analysis of the SR based absorber are carried out using CST Microwave Studio based on frequency domain solver and optimized final dimensions are given in Table 1. As seen in Figure 2, the absorber is excited by incident electromagnetic wave where electric field vector $E$, magnetic field vector $H$ and propagation vector $k$ are along $y, x$ and $-z$ directions, respectively. Also, boundary conditions are selected unit cell, unit cell and open (add space) for $x, y$ and $z$ axes, respectively.

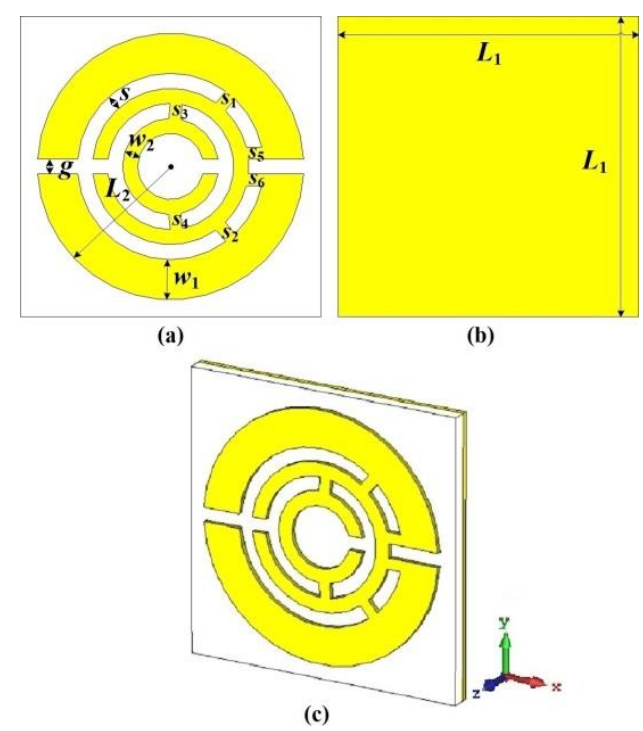

Figure 1. (a) Front, (b) back and (c) perspective schematic view of the proposed split ring absorber with design parameters of a figure caption 
Table 1. Optimal Design Parameters and Values of the Proposed Dual-Band Frequency Absorber with SRR

\begin{tabular}{l|c}
\hline Parameters & Values $(\mathbf{m m})$ \\
\hline$L_{1}$ & 30 \\
\hline$L_{2}$ & 13.4 \\
\hline$w_{1}$ & 5 \\
\hline$w_{2}$ & 1.2 \\
\hline$s$ & 1 \\
\hline$g$ & 1 \\
\hline
\end{tabular}

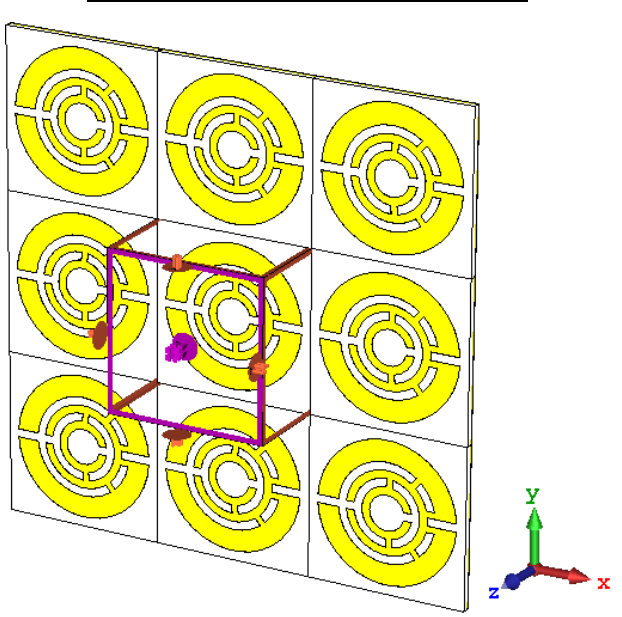

Figure 2. Schematic view of simulation setup.

\section{Results}

Absorption plot obtained from simulation is given in Figure 3. The absorption calculation is as follows:

$$
A(w)=1-R(w)-T(w)
$$

where $A(w), R(w)$ and $T(w)$ are named absorption, reflectance $\left|S_{11}\right|$ and transmittance $\left|S_{21}\right|$, respectively (Landy et al., 2008). A shown in Figure 3, a dual-band operation is achieved at 3.52 $\mathrm{GHz}$ and $5.16 \mathrm{GHz}$ with 0.92 and 0.97 absorption peak, respectively. Bottom side of the absorber structure is covered by using metallic ground plane. In this way, there is no transmission from port 1 to port 2 . As a result, the transmission magnitude is nearly zero and this event is observed in Figure 3.

To investigate the dual-band absorption behavior of the proposed design, $z$-component of electric field distributions for both frequencies have been numerically computed. The simulated electric field distributions on both resonator and ground plane of each design at the frequencies where the absorption peaks occur are illustrate in Figure 4 for the $259^{\circ}$ phase angle. As shown in Figure 4a, it seems that split region of the middle ring of the resonator has more effect on resonance at $3.52 \mathrm{GHz}$. Also, the electric field distributions at the ground plane in the opposite polarity to the field at the resonator demonstrate coupling between patch and ground. This couple causes to form magnetic dipole resonance. According to Figure $4 \mathrm{~b}$, it is seen that the split parts of the outer ring of the resonator are effective on the resonance at $5.16 \mathrm{GHz}$. When electric field distribution of ground plane was examined at $5.16 \mathrm{GHz}$, there is an electric field distribution similar to the behavior at $3.52 \mathrm{GHz}$ in the opposite direction with respect to the resonator.

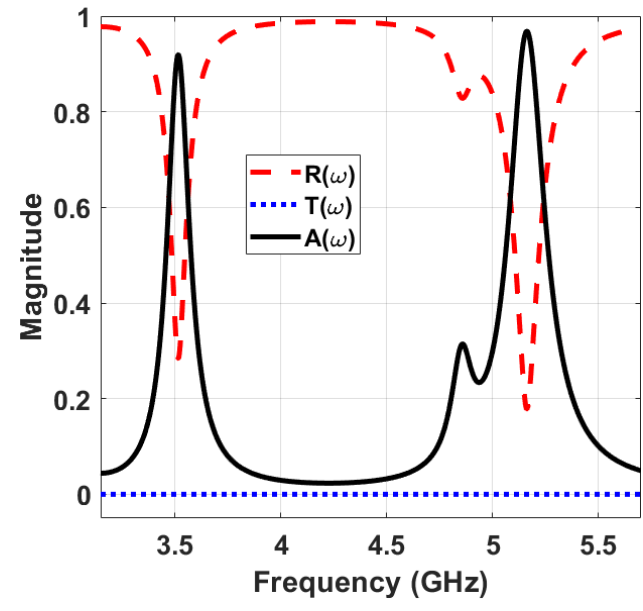

Figure 3. Simulation results for dual-band frequency absorber with split-ring resonator.

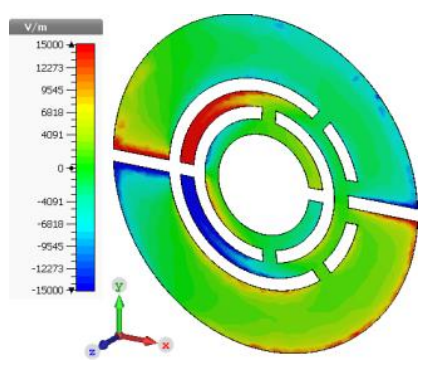

(a)

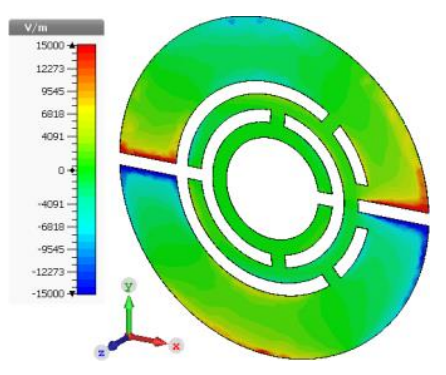

(b)

Figure 4. z-component of electric field distributions on SRR and ground planes at $259^{\circ}$ phase angle for (a) at $3.52 \mathrm{GHz}$, (b) at

\section{$5.16 \mathrm{GHz}$}

To evaluate the contributions of the study, the proposed SRR-based absorber design is compared with the previously reported dual or multi bands absorbers in terms of dimensions, resonance frequencies and number of bands as given in Table 2. It can be clearly seen that, considering the lowest resonance frequency, the electrical size of the proposed design is fairly smaller than the others. 
Table 2. Sizes Comparisons with Reported Works in Literature.

\begin{tabular}{l|c|c|c}
\hline References & Frequencies $(\mathbf{G H z})$ & Number of Band & Dimensions of Unit Cell $\left(\boldsymbol{\lambda}_{\mathbf{0}}\right)$ \\
\hline This Work & $3.52,5.16$ & 2 & $0.352 \times 0.352$ \\
\hline Zheng et al., & $6.69,7.48,8.67,9.91$ & 4 & $0.446 \times 0.446$ \\
\hline Zhai et al., & $5.95,12.25$ & 2 & $0.365 \times 0.365$ \\
\hline Guo et al., & $6.30,9.75,12.35$ & 3 & $0.420 \times 0.420$ \\
\hline Deng et al., & $101.25,108.75,129$ & 3 & $0.493 \times 0.493$ \\
\hline
\end{tabular}

\section{Conclusions}

In this paper, SRR-based dual-band absorber design for WiMAX and WLAN bands has been introduced. In the design, SR resonator of the absorber has miniature size allowing dual band absorption operation. Also, the metallic loadings placed between the rings enable fine absorption frequency tuning. The numerical results show that the proposed design performs dualband operation at the designated 3.52 and 5.16 frequencies with 0.92 and 0.97 absorption peaks. Thanks to these attractive features, the proposed absorber can be a good candidate for various applications such as EMI/EMC, wireless communication and WiMAX/WLAN operations.

\section{References}

Al-Badri K. S., Cinar A., Kose U., Ertan O., \& Ekmekci E. (2016). Monochromatic tuning of absorption strength based on angle-dependent closed-ring resonator-type metamaterial absorber. IEEE Antenn Wirel Pr, 16, 1060 - 1063.

Bakir M., Karaaslan M., Dincer F., Akgol O., \& Sabah C. (2016). Electromagnetic energy harvesting and density sensor application based on perfect metamaterial absorber. Int J Mod Phys B, 30(20), 1650133.

Basaran S. C., \& Erdemli Y. E. (2008). Dual-band split-ring antenna design for WLAN applications. Turk J Elec Eng Comp Sci, 16(1), $79-86$.

Cinar A., \& S. C. Basaran. (2018, October). A Compact DualBand Textile Antenna Design For Wearable Applications. 3rd International Mediterranean Science and Engineering Congress (IMSEC 2018) (pp. 937-9399).

Deng G., Xia T., Yang J., \& Yin Z. (2018). Triple-band polarisation-independent metamaterial absorber at mm wave frequency band. IET Microw Antennas Propag, 12(7), 11201125 .

Ekmekci E., \& Demir E. (2015). On/off switching of absorption spectra by layer shifting for double-layer metamaterialbased absorber. IEEE Antenn Wirel Pr, 15, 532 - 535.

Genikala S., \& Ghosh A. (2020, October). Design of Polarization-Insensitive Dual band Microwave Absorber for EMI/EMC Applications. In 2020 IEEE 5th International Conference on Computing Communication and Automation (ICCCA) (pp. 433-436).
Guo X. R., Zhang Z., Wang J. H., \& Zhang J. J. (2013). The design of a triple-band wide-angle metamaterial absorber based on regular pentagon close-ring. J Electromagn Waves Appl, 27(5), 629-637.

Jain P., Singh A. K., Pandey J. K., Bansal S., Sardana N., Kumar S., Gupta N., \& Singh A. K. (2021). An Ultrathin Compact Polarization-Sensitive Triple-band Microwave Metamaterial Absorber. J Electron Mater, 50(3), 1506-1513.

Landy N. I., Sajuyigbe S., Mock J. J., Smith D. R., \& Padilla W. J. (2008). Perfect metamaterial absorber. Phys Rev Lett, 100(20), 207402-1 - 207402-4.

Liu X., Tyler T., Starr T., Starr A. F., Jokerst N. M., \& Padilla W. J. (2011). Taming the blackbody with infrared metamaterials as selective thermal emitters. Phys Rev Lett, 107(4), 045901 .

Mishra N., Khusboo K., \& Raghvendra K. C. (2018). An ultrathin polarization independent quad-band microwave absorber-based on compact metamaterial structures for EMI/EMC applications. Int J Microw Wirel Technol, 10(4), $422-429$.

Sen G., Banerjee A., Kumar M., Islam S. N., \& Das S. (2016, December). A dual band metamaterial inspired absorber for WLAN/Wi-MAX applications using a novel I-shaped unit cell structure. In 2016 Asia-Pacific Microwave Conference (APMC) (pp. 1-3).

Sen G., \& Ghosh A. (2019, December). Dual Band Metamaterial Absorber Using Concentric Split-Ring Structures for Wireless Applications. In 2019 IEEE International Conference on Advanced Networks and Telecommunications Systems (ANTS) (pp. 1-4).

Tak J., \& Choi J. (2016). A wearable metamaterial microwave absorber. IEEE Antenn Wirel Pr, 16, 784 - 787.

Wang B. X. (2016). Quad-band terahertz metamaterial absorber based on the combining of the dipole and quadrupole resonances of two SRRs. IEEE J Sel Top Quant, 23(4), 1-7.

Zhai H., Li Z., Li L., \& Liang C. (2013). A dual-band wide-angle polarization-insensitive ultrathin gigahertz metamaterial absorber. Microw Opt Technol Lett, 55(7), 1606-1609.

Zheng D., Cheng Y., Cheng D., Nie Y., \& Gong R. Z. (2013). Four-band polarization-insensitive metamaterial absorber based on flower-shaped structures. Prog In Electromagn Res, 142, 221-229. 